International Journal on Emerging Mathematics Education (IJEME)

Vol. 1, No. 2, September 2017, pp. 169-176

P-ISSN: 2549-4996, E-ISSN: 2548-5806, DOI: http://dx.doi.org/10.12928/ijeme.v1i2.5780

\title{
Adversity Quotient in Mathematics Learning (Quantitative Study on Students Boarding School in Pekanbaru)
}

\author{
1Zubaidah Amir MZ, ${ }^{1}$ Risnawati, ${ }^{1}$ Annisa Kurniati, ${ }^{2}$ Rully Charitas Indra Prahmana \\ ${ }_{1}^{1}$ Universitas Islam Negeri Sultan Syarif Kasim, Jl. Subrantas Km. 15, Rimba Panjang, Pekanbaru, Riau, Indonesia \\ 2Universitas Ahmad Dahlan, Jl. Pramuka Kav. 5, Pandeyan, Umbulharjo, Yogyakarta, Indonesia \\ e-mail: zubaidah.amir@uin-suska.ac.id
}

\begin{abstract}
Abstrak
Tujuan dari penelitian ini adalah untuk menganalisis daya juang/Adversity Quotient (AQ) siswa dalam pembelajaran matematika ditinjau dari aspek gender. Penelitian ini merupakan studi survey kuantitatif pada siswa di MTs Pondok Pesantren Al-Munawawarah Pekanbaru, siswa kelas VIII yang terdiri dari 75 siswa perempuan dan 63 siswa laki-laki. Data dikumpulkan melalui skala AQ dan dianalisis dengan statistik deskriptif dan inferensial (uji-t). Indikator AQ terdiri dari control, origin, ownership, reach, dan endurance. Hasil analisis secara deskriptif menunjukkan bahwa terdapat perbedaan masing-masing mean indikator untuk kedua kelompok, namun dari hasil analisis uji-t menunjukkan bahwa tidak terdapat perbedaan AQ matematis siswa antara kedua kelompok jender siswa. Melalui uji variansi, AQ Matematis siswa pada kedua kelompok homogen. Indikator AQ siswa laki-laki berkategori tinggi yaitu endurance dan reach. Sedangkan pada siswa perempuan yaitu aspek control. Penelitian ini memberikan kontribusi dalam studi literatur untuk mengidentifikasi AQ siswa serta upaya yang dapat dilakukan untuk meningkatkan AQ siswa dalam pembelajaran matematika.
\end{abstract}

Kata kunci: adversity quotient, jender, metakognitif

\begin{abstract}
The aim of this study is to analyze students' Adversity Quotient (AQ) in mathematics learning viewed from gender aspect. This study is quantitative survey study on students in MTs AlMunawarah Boarding School, Pekanbaru. The subjects of study are $8^{\text {th }}$ grade students consisting of 75 girls and 63 boys. Data are collected by AQ scale and analyzed with statistic descriptive and inferential (test- $t$ ). The indicator of AQ consist of control, origin, ownership, reach and endurance. The result of descriptive analysis shows that there is difference in mean of each indicator for two groups, but analysis of test-t shows that there is no difference in students' mathematical AQ for two group of gender. Through variance test, students' mathematical AQ in two groups is homogeneous. The indicator of $\mathrm{AQ}$ in boys which is categorized as high are endurance and reach. While, the indicator in girls is aspect of control. This study contributes to literature study in identifying students' AQ and the effort done to enhance students' AQ in mathematics learning.
\end{abstract}

Keywords: adversity quotient, gender, metacognitive

How to Cite: MZ, Z.A., Risnawati, Kurniati, A., \& Prahmana, R.C.I. (2017). Adversity quotient in mathematics learning (Quantitative study on students boarding school in Pekanbaru). International Journal on Emerging Mathematics Education, 1(2), 169-176. http://dx.doi.org/10.12928/ijeme.v1i2.5780

\section{INTRODUCTION}

Mathematics learning is aimed to create students attitude to appreciate the usefulness of mathematics in learning the problem, and to increase self confidence when solving the problem (NCTM, 1989; Ernest, 1991; Depdiknas, 2006; Prahmana \& Kusumah, 2016). NCTM further explained that mathematics learning aimed to help students in developing their confidence that they have mathematical ability and they 
can control their own success or failure. In other word, mathematics education has central role in helping students to live productively in society and ability to solve all problems that arise in it. Given the importance of that role, it is expected that mathematics education not only emphasizes on material mastery, but also on development of social, affective, mental, and psychological aspects. It is important to study further the psychological aspect in mathematics learning. One of psychological aspects in learning is struggle power in facing the obstacles which is called Adversity Quotient (AQ).

AQ means one's struggle power in facing obstacles/barrier. This is in line with Stoiz (2006) who stated that Adversity Quotient is perseverance in overcoming the obstacles in climbing the peak of success desired. AQ is needed for students in facing problem in learning. This was confirmed by Matore et. al. (2015) that in education perspective, AQ is ability needed to kept struggled when students face difficulty in achieving their success. This was also confirmed by Parvathy et. al. (2014) that students face many situations or obstacles in their daily life, and to overcome or solve this problem, Adversity Quotient is needed. Further they said that students who have good AQ will be able to endure in facing various difficulty in mathematics learning. Therefore, it is necessary to study $A Q$ in mathematics learning.

$\mathrm{AQ}$ has four key dimensions which underlie the arrangement of $\mathrm{AQ}$ measurement tool on students. These four key dimensions which are defined by Stoltz (2006) are: 1) Control, 2) Origin and Ownership, 3) Reach and 4) Endurance. Dimension of control related to a person's response to difficulty either slow or spontaneous. Dimension of ownership the extent to which a person feels he or she can improve the situation. Dimension of reach is the extent to which difficulty is derived to pervade his or her life. Dimension of endurance reflect how a person perceive the difficulty and therefore he or she capable to endure in passing through it. These dimensions can be measured and resulted in overall score. This score determine the capacity of a person to face difficulty.

According to Stolz (2000), there are three types of $A Q$, namely: quitter type (low $A Q$ ), camper type (medium AQ), and climber type (high AQ). Quitter type is typical of a student who tries to get away from the problems. The characteristics of student with this type are: has minimal effort, when confronted with difficulty he will retreat, and do not dare to face the problem. Students with quitter type are those who think that math is complicated and confusing. They lack of motivation, so when encounter few difficulties in solving math problem, they will give up and stop with effortless. Camper type is typical of students who don't want take a big risk and feeling satisfy with the condition or circumstance they had achieved at that time. In learning mathematics, students with camper type not try as maximal as possible. They think that they don't need high mark, the importance is they pass. Climber type is typical students who have goal or target. To achieve that goal, they can try to achieve it with perseverance. Besides, they also have courage and high discipline. Students with climber type are those who like learning mathematics. They always accomplish the tasks given by teacher on time. If they find mathematical problems which are difficult to be solved, then they will try as maximal as possible until they can solve it.

Mathematics learning is considered as difficult lesson and intimidating for students (Sriyanto, 2007). Students who have good AQ will be able to face any challenges that exist in mathematics. Therefore, how students' AQ in mathematics learning needs to be studied further. The equally important is gender factor. Gender difference lead to difference in physiology and affect psychological differences in

IJEME, Vol. 1, No. 2, September 2017, 169-176 
learning (Amir MZ, 2013). There are many differences between boys and girls in learning mathematics. Based on result study of Wigfield and Meece (1988) in Amir MZ (2013) who assessed age and gender differences, response from boys and girls through MAQ concluded that the negative response from girls toward mathematics is stronger that boys in age of $6.7,9$, and 11 years old. Based on explanation above, researcher is interested to study further mathematical AQ of students in MTs level in MTs Al-Munawarah Boarding School, Pekanbaru. Therefore, there are two research questions in this paper. First, are there any differences between boys and girls' AQ in mathematics learning? Secondly, how is mathematical AQ of students in MTs AlMunawarah Boarding School, Pekanbaru?

\section{RESEARCH METHOD}

This research is a quantitative study on students of MTs Al-Munawarah Boarding School Pekanbaru. The population is all students in that school. Sample in this study are $8^{\text {th }}$ grade students who consist of 75 girls and 63 boys. Data is collected by AQ scale. Data is analyzed by descriptive statistic and inferential statistic. Descriptive statistic is showed by average value (mean), percentage (\%), and give labels for each category of indicator (low, moderate, high) and AQ from each student: quitter (very low, low), champer (moderate), and climber (high, very high). Inferential statistic is showed by comparative test ( $\mathrm{t}$-test) with data is normal distributed and homogeneous.

\section{RESULTS AND DISCUSSION}

\section{Students' AQ toward Mathematics}

Girls consist of 75 students. While, boys consist of 63 students. Analysis of students' mathematical AQ is based on category of AQ which is presented in Table 1 and Figure 1.

Table 1. Data of Students' AQ Category toward Mathematics

\begin{tabular}{lcrrrl}
\hline Category & \multicolumn{2}{c}{ Quitter } & \multicolumn{2}{c}{ Champer } & \multicolumn{2}{c}{ Climber } \\
\cline { 2 - 6 } & Very Low & Low & Moderate & High & Very High \\
\hline Boys & 0 & 6 & 15 & 33 & 9 \\
Girls & 0 & 3 & 24 & 45 & 3 \\
\hline
\end{tabular}

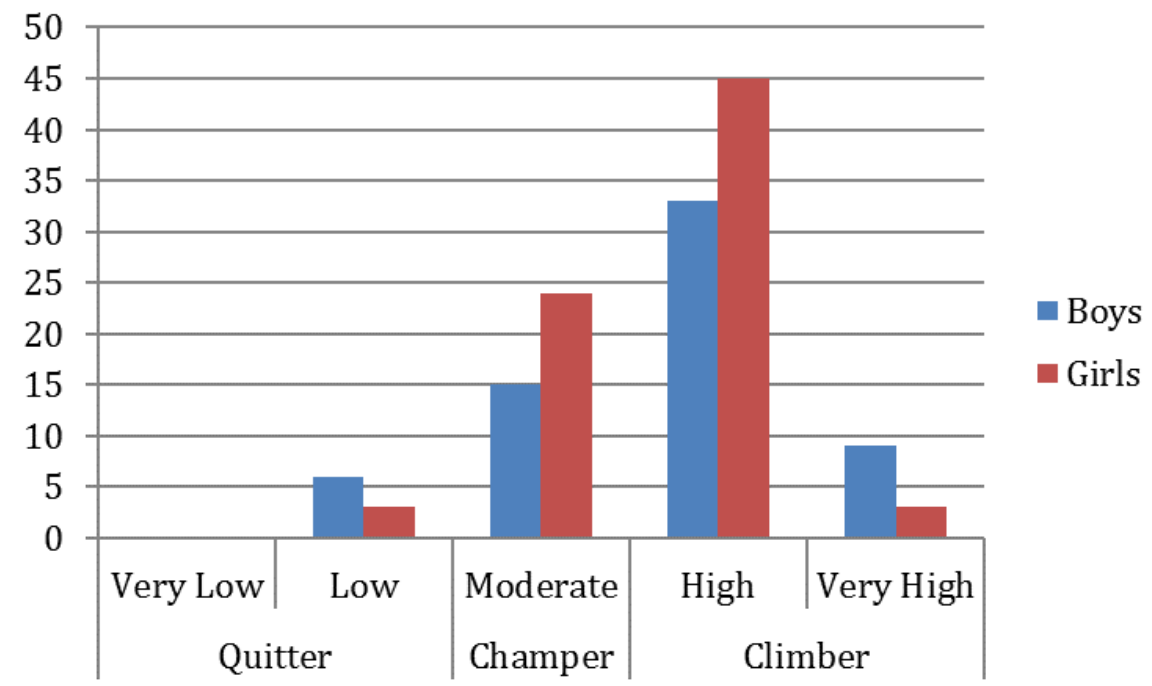

Figure 1. Category of Student's Math Adversity Quotient with Gender 
From Table 1 and Figure 1, they appears that for boys there are 9 students who are categorized as very high $\mathrm{AQ}$, and only 3 students who are categorized as very high. For category of high AQ there are many girls than boys, that is, 45 girls and 33 boys. Similarly with category of moderate AQ, there are 24 girls and 15 boys in this category. While, for category of low AQ, there are 6 boys and 3 girls. None of students both boys and girls is in each low category.

For category of AQ climber there are 90 students with distribution of 42 boys and 48 girls. Thus descriptively there are differences between boys and girls for each category of AQ. Of three categories of AQ (Quitter, Champer, Climber), most students are in category of AQ climber, which is high and very high. Percentage of each category can be seen from Table 2 and Figure 2. They appears that more than $50 \%$ boys and girls are in high category, and less than $10 \%$ boys and girls are in low category

Table 2. Percentage of AQ Category

\begin{tabular}{lclc}
\hline Category & Quitter \% & Champer \% & Climber \% \\
\hline Boys & 9.52 & 23.81 & 66.67 \\
Girls & 4 & 32 & 64 \\
\hline
\end{tabular}

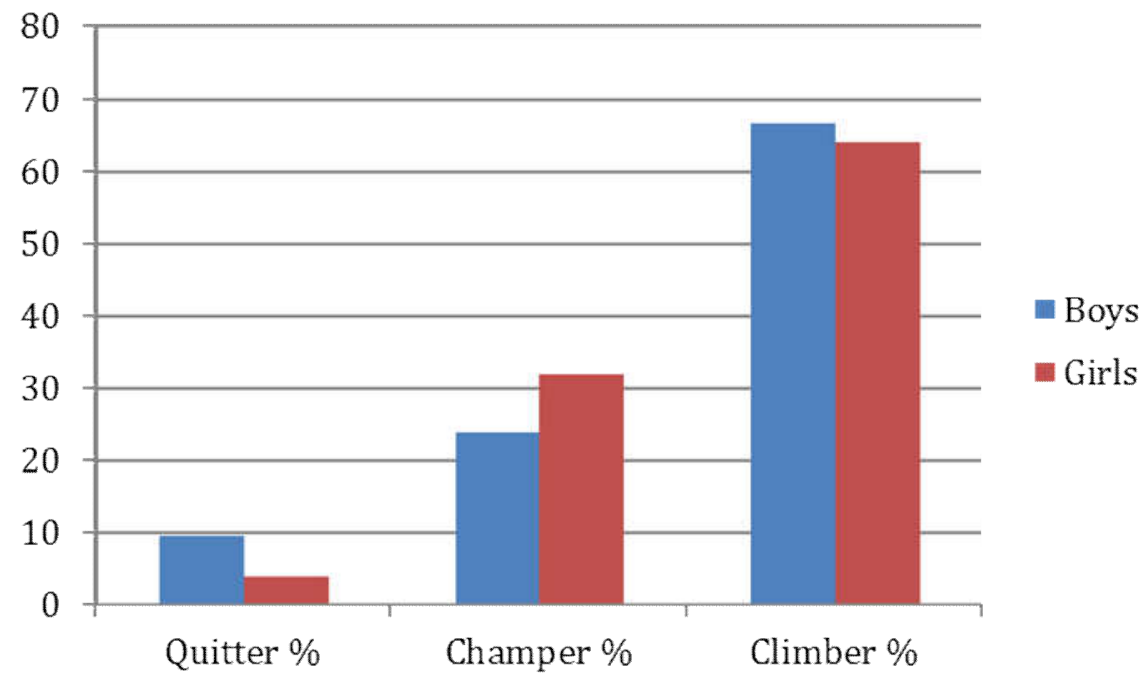

Figure 2. Percentage AQ Category

\section{Indicator of Adversity Quotient (AQ)}

Students' mathematical AQ consist of five indicators with each indicator consist of several statement items. AQ scale is attached. The following is table of percentage of students' AQ grouping in overall.

Tabel 3. AQ Indicators of Students by Gender

\begin{tabular}{lcc}
\hline \multicolumn{1}{c}{ Indicator } & Boys (\%) & Girls (\%) \\
\hline Control & 64.05 (moderate) & 57.9 (moderate) \\
Origin & 70.32 (moderate) & 44.13 (moderate) \\
Ownership & 71.84 (moderate) & 56.8 (moderate) \\
Reach & 83.49 (High) & 57.6 (moderate) \\
Endurance & 80.57 (High) & 54.24 (moderate) \\
\hline
\end{tabular}

IJEME, Vol. 1, No. 2, September 2017, 169-176 
From Table 3, four of five indicators of girls AQ are more than $50 \%$ and only one which is less than $50 \%$. It means that all indicators are categorized as moderate. While for boys, all indicators are more than 50\%. There are two indicators which in high category and the others are in moderate category.

Table 4. Mean of Recapitulation AQ Indicator

\begin{tabular}{ccc}
\hline Indikator & Boys & Girls \\
\hline Control & 67.25 (moderate) & 72.38 (moderate) \\
Origin & 73.83 (moderate) & 55.2 (moderate) \\
Ownership & 75.43 (moderate) & 71 (moderate) \\
Reach & 87.67 (High) & 72 (moderate) \\
Endurance & 84.6 (High) & 67.8 (moderate) \\
\hline Mean & 77.76 (Moderate) & 67.68 (Moderate) \\
\hline
\end{tabular}

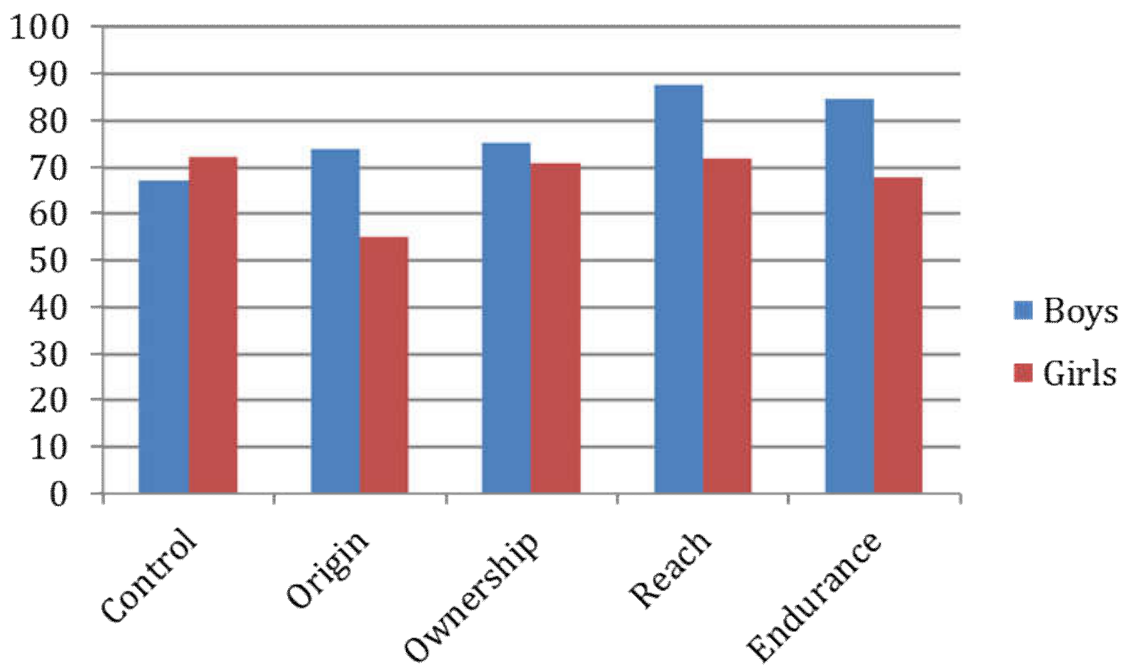

Figure 3. Mean Recapitulation AQ Indicator

Table 4 and Figure 3 show that for boys, indicator of control is the lowest indicator among the other indicators. As for girls, the lowest indicator is origin which is differ with boys. In girls, aspect of control is the highest category, while aspect of control in boys is categorized as moderate. In boys, aspect of reach is highest compared to another four indicators.

In the other word, girls tend to feel that difficulty/challenges they face is bigger than the strength they have. But behind that, girls have aspect of good self control. This is differ with boys, in which aspect of self control is low, but they have endurance in facing difficulty, so it does not enter the side in his life.

Data of boys' AQ variance which is obtained is 159.39, while data of girls' AQ variance is 98.89. This shows that data of boys' AQ is more varied compared to girls, and category of girls' AQ is more homogenous compared to boys. However, through inferential statistic, variance test in two group of students, it is obtained that F 0.6 is less than $\mathrm{F}$ critical 1.6. so it can be concluded than data of two distribution classes is homogeneous. it give conclusion that there is no difference of diversity of AQ in two groups of gender. But, analysis is continued through test-t comparison test. 
Through difference test (t-test), data shows t 1.78 for significant level of $5 \%$ which is smaller than the critical $t$. It concludes that there is no difference in mathematical AQ between boys and girls. The mean score of indicator in boys and indicator in girl are (77.76) and (67.68) respectively. This is the same with study result of Nikam et. al. (2013) who compared AQ of students age 13-15, that there is no difference between girls and boys in intelligence, decision making ability and risk taking ability.

Even though there is no difference in students' AQ with inferential statistic, but descriptively it can be seen from each indicator as explained above, mean of AQ indicator in boys is higher than girls. However, in this study its effect on students' learning outcome, motivation, and self confident had not evaluated. Some studies suggested that AQ influence several aspects of learning as explained by Methavee (2004) (in Pangma et. al., 2009) that adversity quotient from level 4 students in Nongkai Province and they found that 7 variables including emotional intelligence, self concept, motivation, democratic training, dominant desire, responsibility and stress were related to adversity quotient at 0.01 level of significance.

From descriptive data analysis, control AQ in girls is higher than in boys. Haralambos and Horlborn (2004) suggested that girls are more motivated and more diligent than boys in doing school work. Thus, girl students are more able. It supports the results of this study.

When you see the $A Q$ indicators, a student who has ability to control the response in studying is more resilient and not easily discouraged. It is associated with aspects of process control in student's own thinking. If students are able to think about the process of thinking, then they will understand the nature of difficulty in learning mathematics and what they had planned to overcome these difficulties. In other words, students need to get used to control thinking process called metacognition. Metacognition is defined as awareness of thinking about thinking (Amir MZ and Wahyudin, 2016). This is in accord with opinion of Schoenfeld (1992) in Gartmann and Freiberg (2012) that metacognition is a habit in controlling the process of cognitive behavior, control or self-monitoring of one's thought processes.

Swanson defines metacognition as "....the knowledge and control one has over thinking and learning activities..." (Kramarski et. al., 2002: 225). Schraw (1998) affirmed that there is effort needed to build students awareness, that metacognition is important and it influence academic success. This is confirmed by Sweeney (2013) that metacognition is critical to academic success. This is in accord with Pannaoura and Philippou (2005) in Runisah et. al. (2017) that if we not aware of his/her process and cognitive ability, then we will not be able to improve our performance. Metacognitive skill are ability to control the learning process, from the planning stage, choosing the right strategy, and then monitor progress in learning and simultaneously correcting any errors that occur to understand the concept, analyze the effectiveness of selected strategy (Amir MZ et. al., 2017). Therefore, students need to develop metacognitive skills in mathematics.

Schoenfeld (1992) identified three categories of metacognition in mathematics, namely 1) Belief and intuition, 2) Knowledge of thinking process, 3) self-awareness or self-regulation. Furthermore, he explained that awareness of self-regulation can be considered using the management approach as whole, planning solving strategies, monitoring and control methods during solution process, allocate the result, decide what should be done and how long problems is resolved. This is highly related to the effort to resolve problems and face challenges and difficulties. Thus the metacognitive

IJEME, Vol. 1, No. 2, September 2017, 169-176 
based learning need to developed in learning mathematics to increase students' self control, so it give positive effect on AQ' students.

\section{CONCLUSION}

Based on analysis, it can be concluded that there is no significant difference between $A Q$ in boys and girls in MTs Al-Munawaroh Pekanbaru. However, descriptively it can be seen that the average of $A Q$ in boys is higher than girls. Based on AQ indicators, it can be concluded that boys are more likely capable to restrict the variety of mathematical problems encountered when compared to girls. In addition, boys have more endurance when compared to girls. However, girls are more able to control themselves in responding difficulties in mathematics than boys. The aspects of thinking and behavior control are part of metacognitive. Therefore, more research is needed on learning strategies in an effort to enhance students' $\mathrm{AQ}$, in this case is learning metacognitive.

\section{REFERENCES}

Depdiknas. (2006). Peraturan Menteri Pendidikan Nasional Republik Indonesia Nomor 20 tahun 2006. Jakarta: Depdiknas.

Ernest, P. (1991). The Philosophy of Mathematics Education. London: Falmer

Gartmann, S., \& Freiberg, M. (2012). Metacognition and mathematical Problem Solving: helping student to ask The Right Questions. The Mathematics Educator, 6(1), 913.

Haralambos \& Holborn. (2004). Sociology: Themes and Perspectives Sixth Edition. London: Harper Collins Publisher.

Kramarski, B., Mevarech, Z.R., \& Arami, M. (2002). The effects of metacognitive instruction on solving mathematical authentic tasks. Educational Studies in Mathematics, 49(2), 225-250.

Matore, M.E.E.M., Khairani, A.Z., \& Razak, N.A. (2015). The influence of AQ on the academic achievement among Malaysian Polytechnic students. International Education Studies, 8(6), 69-74.

MZ, Z.A. (2013). Perspektif gender dalam pembelajaran matematika. Marwah: Jurnal Perempuan, Agama Dan Gender, 12(1), 15-31.

MZ, Z.A., \& Wahyudin. (2016). Exploration of metacognitive ability at elementary school students in learning mathematics (Case study in $1^{\text {th }}$ Grade students of elementary school). Journal of Innovative Technology and Education, 3(1), 179-184.

MZ, Z.A., Wahyudin, \& Turmudi. (2017). Metacognition think aloud strategies in setting cooperative think-pair-share/square to develop students' math problem solving ability (Comparative study on students of Madrasah Tsanawiyah Boarding/nonBoarding school in Pekanbaru). Advances in Social Science, Education and Humanities Research (ASSEHR), 57. Atlantis Press.

NCTM. (1989). Curriculum and Evaluation Standards For School Mathematic. Virginia: NCTM.

Nikam, V.B., \& Uplane, M.M. (2013). Adversity quotient and defense mechanism of secondary school student. Universal Journal of Educational Research, 1(4), 303308. 
Pangma, R., Tayraukham, S., \& Nuangchalerm, P. (2009). Causal factors influencing adversity quotient of twelfth grade and third-year vocational students. Journal of Social Sciences, 5(4), 466-470.

Parvathy, U., \& Praseeda, M. (2014). Relationship between adversity quotient and academic problems among student teachers. IOSR Journal of Humanities and Social Science, 19(11), 23-26.

Prahmana, R.C.I., \& Kusumah, Y.S. (2016). The hypothetical learning trajectory on research in mathematics education using research-based learning. Pedagogika, 123(3), 42-54.

Runisah, Herman, T., \& Dahlan, J.A. (2017). Using the 5e learning cycle with metacognitive technique to enhance students' mathematical critical thinking skills. International Journal on Emerging Mathematics Education, 1(1), 87-98.

Schoenfeld, A.H. (1992). Learning to think mathematically: Problem solving, metacognition, and sense-making in mathematics. In D. Grouws (Ed.), Handbook for Research on Mathematics Teaching and Learning (pp. 334-370). New York: MacMillan.

Schraw, G. (1998). Promoting general metacognitive awareness. Instructional Science, 26(1), 113-125.

Sriyanto. (2007). Strategi Sukses Menguasai Matematika. Jakarta: PT. Buku Kita.

Stoltz, P.G. (2006). Editors. T. Hermaya. Adversity quotient mengubah hambatan menjadi peluang. Jakarta: PT Gramedia Widia sarana Indonesia.

Stoltz, P.G. (2010). Adversity Quotient Work: Finding Your Hidden Capacity For Getting Things Done. New York: Harper Collins.

Sweeney, C.M. (2010). The metacognitive functioning of middle school student with and without learning disabilities during mathematical problem solving. Dissertations. Miami: University of Miami.

IJEME, Vol. 1, No. 2, September 2017, 169-176 